\title{
The effect of dietary doum supplementation on productive and reproductive performance of does rabbits in Upper Egypt
}

\author{
Hassanien, H.H.M. ${ }^{2}$, A.A. Baiomy ${ }^{1}$, H.A. Hassan ${ }^{1}$ and H. Badry ${ }^{1 *}$
}

\begin{abstract}
${ }^{1}$ Animal and Poultry Department, Faculty of Agriculture, South valley University, Qena, Egypt
${ }^{2}$ Animal and Poultry Production Department, Faculty of Agriculture, Beni Suef University, Egypt
\end{abstract}

\begin{abstract}
The objective of this work was to study the effect of Doum (Hyphaenethebaica) supplementation on productive and reproductive performance of rabbit does in Upper Egypt during spring season. A total of 6 months old 160 does including 80 California (CAL) and 80 Newzland (NEZ) rabbits with average initial body weight $3.150 \pm 0.05 \mathrm{~kg}$ was randomly divided into four groups of 20 does each/breed (CAL or NEZ). The study was conducted in a $4 \times 2$ factorial design. Doum in the basal diet was supplemented for each strain with 4 levels $0,0.3$, $0.6,0.9 \mathrm{~g}$ doum $\mathrm{kg}$ diet and offered to 2 rabbit breeds New Zealand White (NZW) and Californian (CAL) in upper Egypt. Doum in the basal diet was improved performances of rabbits compared to control. California does show significant higher productive and reproductive performances and lower mortality rate compared to the NEZ breed.
\end{abstract}

Keywords: Doum, Reproductive, Fertility, Milk, Female rabbits.

\section{Introduction}

The World Health Organization has encouraged research on medicinal plants as ant diabetics (Shehu et al., 2014) and (Abdel-Rahim et al., 2011). Doum (Hyphaenethebaica) is an African palm tree, common in Upper Egypt (Aremu, 2011), originated from Nile valley an edible fruit which is glubose-quandrangular, about $6 \times 5 \mathrm{~cm}$ with a shiny orange-brown to deep chestnut skin (epicarp).The rind (mesocarp) in some palm is inedible but of other it is very palatable, highly aromatic and sweet with a taste like ginger bread hence the English name. When eaten it serves as vermifuges and parasite

\section{*Corresponding author: Hanan Badry}

Email: nona.kind84@gmail.com

Received: January 28, 2020;

Accepted: June 15, 2020;

Published: June 17, 2020. expellant (Burkill,1997). The chloroform extract of this fruit also improves spermatic count in male rats at low concentration (Hetta and Yassin 2006) and but decreases it at high concentration (Hetta et al., 2005).It was considered sacred by the Ancient Egyptians and its seeds were found in many pharaoh's tombs e.g Tutankhamun's tomb (Hetta et al., 2005). many researches have been conducted to explore the use of phytogenic as alternative to antibiotic in animal nutrition (Abdel-Wareth et al., 2012; 2014; 2018; 2019; 2020; Abdel-Wareth, 2016; Fawaz et al., 2019; Amer et al., 2020). Mervat Ghazal, (2016) showed that, Hy-Plus rabbit does fed diets supplemented with doum using bucks treated with the same treatment, recorded conception and kindling rates; litter size and weight and bunny weight at birth and at weaning significantly, and in descending order, than of those recorded by does fed un-supplemented 
diet.Also, it can be noticed that doum supplementation supplementation reduces abortion and mortality rate. It is clear from above studies that, the fertilizing ability of rabbit semen treated with doum show better results. Also, improving the survivability due to transfer of active material in it ( $\mathrm{Zn}, \mathrm{Mn}$ and copper) which can be used as antioxidant and antimicrobial to the milk of does to the bunny, so the bunny get healthy and its immune system improved and disease resistance increased which reflect on decreasing the mortality rate and improve the fertility rate, litter size and weight and individual weight, even at birth or at weaning(Mervat Ghazal 2016). Ali and Ghazal (2013) indicated that, milk yield and composition (protein; fat; lactose and ash) improved significantly due to diet supplemented with doum. Keeping the merits of doum into view. Our previous research indicated physiological response of Doum on rabbits (Hassanien et al., 2019). The present study was conducted on the effect of dietary doum supplementation on productive and reproductive performance of does rabbits in Upper Egypt.

\section{Materials and Methods}

The present experimental work was carried out at the Experimental Farm of Poultry Production Department, Faculty of Agriculture South Valley University, Qena. This study was undertaken during the spring season of Qena City in the period from April to June 2017. The investigation was carried out under warm conditions having average ambient temperature ranging from $25.8^{\circ} \mathrm{C}(\min )$ to $41.1^{\circ} \mathrm{C}(\max )$, relative humidity $16.3 \%$ minimum to $41.5 \%$ maximum Table 1 showed maximum, minimum and estimation of average air temperature $\left(\mathrm{C}^{0}\right)$ and relative humidity during the experimental period.

Temperature-humidity index (THI) was calculated according to Marai et al. (2001):

$\mathrm{THI}=\mathrm{db}{ }^{\circ} \mathrm{C}-\left[(0.31-0.31 \times \mathrm{RH}) \times\left(\mathrm{db}{ }^{\circ} \mathrm{C}-\right.\right.$ 14.4)]

Where, $\mathrm{db}{ }^{\circ} \mathrm{C}=$ dry bulb temperature and $\mathrm{RH}=$ relative humidity $\%$. The THI values were classified as absence of heat stress $(<27.8)$, moderate heat stress (27.8-28.8), severe heat stress (28.9-29.9) and very severe heat stress (>30.0) (Marai et al., 2002).

Table1. Least square means and standard errors of air temperature $\left(\mathrm{AT},{ }^{\circ} \mathrm{C}\right)$ and relative Humidity $(\mathrm{RH}$, $\%$ ) in the area of south valley experimental animal farm during the period of study.

\begin{tabular}{|c|c|c|c|c|c|c|c|}
\hline \multirow{2}{*}{ MONTH } & \multicolumn{3}{|c|}{ AIR TEMPERATURE, ${ }^{0} \mathrm{C}$} & \multicolumn{3}{|c|}{ RELATIVE HUMIDITY, \% } & \multirow{2}{*}{ THI } \\
\hline & Minimum & Maximum & Mean & Afternoon & Morning & Mean & \\
\hline APRIL & $15 \pm 0.22$ & $32 \pm 0.19$ & $23.5 \pm 0.37$ & $48.6 \pm 0.27$ & $80 \pm 1.05$ & $64.3 \pm 0.36$ & 22.49 \\
\hline MAY & $25.8 \pm 0.27$ & $41.1 \pm 0.17$ & $33.4 \pm 0.27$ & $16.3 \pm 0.61$ & $41.5 \pm 0.36$ & $28.9 \pm 1.10$ & 29.20 \\
\hline JUNE & $26 \pm 0.29$ & $42 \pm 0.18$ & $34 \pm 0.29$ & $17.8 \pm 0.63$ & $42.5 \pm 0.39$ & $30.15 \pm 0.51$ & 29.68 \\
\hline
\end{tabular}

\section{1 .Animals, management and experimental design:}

In abstract you mentioned 160 does (80 $\mathrm{CAL}+80 \mathrm{NEZ}$ ) but here you state that 128 doe 64 California (CAL) and 64 Newzland (NEZ) rabbits 6 months old with average initial body weight $3.150 \pm 0.05 \mathrm{~kg}$ were randomly divided into four groups of 16 does each/breed (CAL and NEZ). Rabbits were individually housed in galvanized wire cages provided with feeders and automatic stainless- steel nipple drinkers where basal diet and water were offered ad 
libitum. Rabbits were randomly divided into formulation and chemical composition of the four equal groups. Group 1 served as control diets was showed in (Table 2).

(fed basal diet). Groups 2, 3 and 4 fed the basal diet supplemented with $0.3,0.6$ and $0.9 \mathrm{~g}$ doum $/ \mathrm{kg}$ diets. respectively, for 12 weeks

Table 2. Formulation and chemical composition of the diets $(\mathrm{g} / \mathrm{kg})$

\begin{tabular}{|c|c|c|c|c|}
\hline Ingredients $\%$ & Control & tested one ration & $\begin{array}{l}\text { tested two } \\
\text { rations }\end{array}$ & $\begin{array}{l}\text { tested three } \\
\text { rations }\end{array}$ \\
\hline Alfalfa hay & 342 & 342 & 342 & 342 \\
\hline Soybean meal $(44 \% \mathrm{CP})$ & 125 & 125 & 125 & 125 \\
\hline Corn meal & 225 & 225 & 225 & 225 \\
\hline Whole sunflower meal & 70 & 69.7 & 69.4 & 69.1 \\
\hline Doum (Hyphaenethebaica) & - & 0.300 & 0.600 & 0.900 \\
\hline Barley meal & 140 & 140 & 140 & 140 \\
\hline Wheat bran & 50 & 50 & 50 & 50 \\
\hline Beet molasses & 12 & 12 & 12 & 12 \\
\hline Calcium carbonate & 13.72 & 13.72 & 13.72 & 13.72 \\
\hline Calcium diphosphate & 6.71 & 6.71 & 6.71 & 6.71 \\
\hline Sodium chloride & 5 & 5 & 5 & 5 \\
\hline Dl-methionine & 0.570 & 0.570 & 0.570 & 0.570 \\
\hline Vitamin-mineral premix $*$ & 10 & 10 & 10 & 10 \\
\hline Total & 1000 & 1000 & 1000 & 1000 \\
\hline \multicolumn{5}{|c|}{ Calculated chemical composition of the diets\% } \\
\hline Dry matter & 89.2 & 89.8 & 89.5 & 89.5 \\
\hline Crude protein & 17.3 & 17.2 & 17.00 & 17.00 \\
\hline Ether extract & 5.3 & 5.2 & 5.3 & 5.3 \\
\hline Crude fibre & 14.9 & 14.8 & 14.8 & 14.8 \\
\hline Ash & 8.8 & 8.6 & 8.7 & 8.7 \\
\hline Digestible energy $\mathrm{kcal} / \mathrm{kg}$ & 2610 & 2600 & 2600 & 2600 \\
\hline
\end{tabular}

*per kg diet: Vit. A 11,000 UI; Vit. D3 2,000 UI; Vit.B1 2.5 g; Vit.B2 4 g; Vit.B6 1.25 g; Vit.B12 0.01 g; Alphatocopheryl acetate $50 \mathrm{~g}$; Biotine $0.06 \mathrm{~g}$; Vit. K $2.5 \mathrm{~g}$; Niacine $15 \mathrm{~g}$; Folic acid $0.30 \mathrm{~g}$; Dpanthotenic acid $10 \mathrm{~g}$; Choline 600 g; Mn 60 g; Fe 50 g; Zn 15 g; I 0.5 g; Co 0.5 g.

Table 3. Composition and chemical analysis of Doum used in the experiment.

\begin{tabular}{ll|ll}
\hline Items & \multicolumn{1}{l}{} & Items & $\%$ \\
\hline Protein & 6.45 & Potassium & 5.99 \\
Fat & 4.89 & Calcium & 92.24 \\
Fiber & 11.55 & Magnesium & 1.31 \\
Total carbohydrate & 72.89 & Iron & 1.95 \\
Total Sugars & 12.66 & Copper & 1.82 \\
Reducing Sugars & 1.99 & Zinc & 0.04 \\
Elements(mg/100g) & 10.67 & Manganese & 0.09 \\
\hline
\end{tabular}

Recorded by (Hussein et al., 2011). 


\section{Breeding Data Estimation}

The data generated for this study included 128 doe(64 NZW and 64 California) with average initial body weight of $3150 \pm 0.05 \mathrm{~kg}$ and 6 months year .Litter birth and weaning traits investigated included litter size at birth and weaning (No), litter weight at birth and weaning (g), gestation length (days) and preweaning mortality $(\%)$.

\section{Reproductive Traits}

1-Gestation Length (GL): taken in days as the difference between the date of kindling and the date at which successful mating occurred.

2. Litter Size at Birth (LSB): (No) is the number of the doe kindles at the birth.

3. Litter Birth Weight (LBW): (g/litter) is the weight of the kits or kids at birth. Measurement was taken in grams (g), using a digital scale (Mettler Toledo, Top Pan Sensitive Balance, J. Liang Int. Ltd. U.K.

4. Pre-weaning mortality (\%): Litter size at birth (alive) - litter size at weaning/ Litter size at birth (alive) x 100.

5-Growth rate of the kits (GR): is increase in body weight and size of the kits from kindling to the weaning period.

\section{Weaning Traits}

The weaning traits measured included litter size at weaning (LSW) is actual count of weaners alive at weaning. Litter weight at weaning (LWW) is weight of litters taken in $\mathrm{g}$ at weaning.

\section{Does Traits}

These traits included No. of inseminated does No. of pregnant does_Conception rate (\%) which is (No. of pregnant does/ No. of inseminated does)x 100

$$
\mathrm{CR}=\underline{\text { No of does conceived }} \times 100 / 1
$$

No of does mated
Abortion rate (\%) calculated as No. of Abortion does/ No. of inseminated does x 100, No. of kindled does, which is actual count of kindled does, kindling rate $(\%)$ which is calculated as conception rate - Abortion rate, Or, which is No. of kindled does/ No. of inseminated does $x$ 100 , growth rate of kit (g/kit/day) is calculated as bunny weight at weaning (g)-bunny weight at birth $(\mathrm{g}) / 30$

\section{Milk yield}

Milk samples were taken from nursing does individually within each experimental group, on the 21 st day of lactating period (peak of milk production). A part of fresh milk sample was immediately analyzed to estimate milk protein, fat, lactose and ash, by using Milkoscan ${ }^{\circledR}$ analyzer-130 B, N. Foss Electronic-Denmark.

\section{Blood Collection and Analysis}

Blood samples of about $2 \mathrm{ml}$ were taken from two rabbit does in each treatment group. The blood samples were collected at the end of lactation and taken to the laboratory for analysis.To collect the blood sample, a small area from the central ear vein was cleaned with methylated spirit soaked with cotton wool. Blood samples were collected by syringe containing one drop of heparin as anticoagulant (EDTA) to avoid coagulation of the blood samples. The blood samples were later divided into two parts, the first part was used to determine haematological parameters while the second part was centrifuged (15 min, 3500 $\mathrm{rpm}$ ) and surm removed and stored at frozen of $-20^{\circ} \mathrm{c}$. These were later used for oxidative enzyme and hormone analysis. From the samples of the blood collected;

(a) Basic haematology was conducted to check any disease disorder and other related blood disorder such as iron deficiency.

(b) doum content in the blood was determined using oxidative enzyme analysis. 
(c) Reproductive hormones vizfollicule stimulating hormone (FSH) and leutinizing hormone (LH) were equally determined.

NB: The Haematogical parameters taken were $\mathrm{Hb}, \mathrm{PCV}, \mathrm{RBC}, \mathrm{WBC}, \mathrm{N}$ and differential white blood cell, while the oxidative enzyme parameters taken were: doum, MDA, SOD, Glutathione, Glutathione transferase, Glutathione peroxidase, catalase and reduced glutathione.

\section{Methods of Blood Analysis for Various Hematological Parameters}

\section{(1) Hemoglobin (HB\%)}

$0.02 \mathrm{ml}$ of well mixed whole blood was diluted into four mls of drabkins solution. This is measured spectrophotometrically at 546 nanometer wavelength. After measuring the value of $\mathrm{Hb}$ was red from the calibration curve (calorimetrically) according to Van Kampen and Zillestra (1983).

\section{(2) WBC $\left(\mathrm{mm}^{3}\right)$ total white blood cell count:}

The $0.02 \mathrm{ml}$ of blood is diluted with $0.38 \mathrm{ml}$ of diluting fluid. The total blood count is counted using improved neubaur counting chamber.

\section{(3) Differential white blood cell count:}

Tin blood smear is made on a clean grease free slide allowed to dry and stain with lishman stain. The different white blood are then collected as percentages.

\section{(4) RBCs-Red blood cells count:}

All counting methods are based on the dilution of capillary blood or well mixed, correctly anticoagulated venous blood with counting fluids in a special counting pipette. The individual cells are counted in a counting chamber (hemocytometer). Alternatively, electronic counters such as the coulter counter may be used. The coulter counter counts the individual red blood cells of a measured volume of a diluted blood as they pass through a minute orifice guarded by an electric currentflowing between platiunum electrodes. Electronic counters work with a reproducibility of under $+2 \%$. Since the electronic counter enumerates red and white blood cells alike, an error will be introduced if there is a leukocytoissof over 30.000 cells $/ \mathrm{mm} 3$. In this case, the result may be corrected. With certain adjustments, the coulter counter can bealso used to count platelets with a standard error of $+2.85 \%$. The cell counts are red directly from the counter.

\section{(5) Hematocrit - volume of packed red cells $(P C V)$.}

Hemotocrit measure the proportion of red blood cells to surm in a peripheral blood but not in the entire circulation. The hematocrit gives the ratio of total erythrocyte mass to total blood volume. The hematocrit $(\mathrm{Ht})$ reading is recorded as the number of millimeters of packed red cells $/ 100 \mathrm{~mm}$ blood, indicating the volume $(\%)$ of packed red cells/dl blood.

(6)PCV can be measured using Microhematocrit method:

Here a capillary hematocrit tube approximately $7 \mathrm{~cm}$ in length and having a bore of about $1.0 \mathrm{~mm}$ is used. These capillary tubes can be purchased with an anticoagulant already in them to facilitate direct filling from a venous or capillary puncture. Plain tube may be used with blood containing an anticoagulant. Capillary tubes are filled with capillary action, the outside is carefully dried with a piece of gauze, and the opposite end of the tube is sealed. These sealed tubes are then placed in a special high -speed centrifuge with the sealed end near the outside $\mathrm{mm}$ of the centrifuge. The tube is centrifuged for 2 minutes at $12.000 \mathrm{rpm}$, after which the volume of packed cells is read from a scale held against the capillary tube in such a way that the top of the plasma column coincides with the $100 \%$ line and the bottom of the packed red cells falls on thezero line. 


\section{(7) Hormonal parameters:}

FSH (Iu/ml) and LH (iu/ml) The surm concentration of FSH and LH were determined using radioimmunoassay as recommended by (Abraham et al. 1971).

\section{Oxidative Enzyme Parameters Measured:}

\section{(a) Superoxide Dismutase (SOD)}

Superoxide dismutase was assayed according to the method of Misra and Fridovich (1972). $0.1 \mathrm{ml}$ of tissue homogenate was added to the tubes containing $0.75 \mathrm{ml}$ of ethanol and $0.15 \mathrm{ml}$ of chloroform und chilled condition and centrifuged. To $0.5 \mathrm{ml}$ of supernatant, $0.5 \mathrm{ml}$ of $0.6 \mathrm{mM}$ EDTA solution and $0.1 \mathrm{ml}$ of $0.1 \mathrm{M}$ carbonate biocabonate buffer ( $\mathrm{PH} 10.2)$ were added. The reaction was initiated by the addition of $0.5 \mathrm{ml}$ of $1.8 \mathrm{mM}$ epinephrine and the increase in absorbance at 30 second interval for 3 minutes was measured at $480 \mathrm{~nm}$ in a Shimadzu UV spectrophotometer. One unit of superoxide dismutase activity is the amount of protein required for $50 \%$ of inhibition of epinephrine antoxidation minute.

\section{(b) Assay of catalase}

Catalase was assayed according to the method of (Takahara et al 1960). To $1.2 \mathrm{ml}$ of $0.01 \mathrm{~nm}$ phosphate buffer ( $\mathrm{pH} 7.0), 0.5 \mathrm{ml}$ of tissue homogenate was added. The enzyme reaction was started by the addition of $1.0 \mathrm{ml}$ of $0.2 \mathrm{mM}$ hydrogen peroxide solution. The decrease in absorbance was measured at $240 \mathrm{~nm}$ for every 30 seconds up to 3 minutes. The enzyme blank was run simultaneously with $1.0 \mathrm{ml}$ of distilled water instead of hydrogen peroxide. The enzyme activity was expressed as $\mu$ moles of hydrogen peroxide decomposed/minute/mg of protein.

\section{(c) Assay of Glutathione peroxidase (GPX)}

The activity of glutathione peroxidase was assayed by the method of Rotruck et al. (1973).
The reaction mixture consisting of $0.2 \mathrm{ml}$ of $0.8 \mathrm{nM}$ EDTA, $0.1 \mathrm{ml}$ of $10 \mathrm{~nm}$ sodium azide, $0.1 \mathrm{ml}$ of $2.5 \mathrm{nM} \mathrm{H} 202,0.2 \mathrm{ml}$ of GSH, $0.4 \mathrm{ml}$ of $0.4 \mathrm{nM}$ phosphate buffer ( $\mathrm{pH} 7.0$ ) and $0.2 \mathrm{ml}$ of homogenate was incubated at $37 \mathrm{oc}$ for 10 minutes. The reaction was arrested by the addition of $0.5 \mathrm{ml}$ of $100 \%$ TCA and the tubes were centrifuged at $3500 \mathrm{rpm}$. To the supernatant, $3.0 \mathrm{ml}$ of $0.3 \mathrm{M}$ disodium hydrogen phosphate and $1.0 \mathrm{ml}$ of DTNB were added and the color developed was read at $420 \mathrm{~nm}$ immediately. The activity of GPx was expressed as $\mu$ moles of glutathione oxidized/minute/mg of protein.

(d) Assay of Glutathione - S - transferase (GST)

Glutathione - S - transferase was assayed by method of Habig et al. (1974). The reaction mixture containing $1.0 \mathrm{ml}$ of $0.3 \mathrm{nM}$ phosphate buffer ( $\mathrm{pH} 6.5$ ), $0.1 \mathrm{ml}$ of $30 \mathrm{Nm} \mathrm{CDNB}$ and $0.1 \mathrm{ml}$ of tissue homogenate was made up to $2.5 \mathrm{ml}$ with water. The reaction mixture was pre - incubated at $37 \mathrm{oc}$ for 5 minutes. $0.1 \mathrm{ml}$ of 30nM GSH was added and the change in 0.D was measured at $340 \mathrm{~nm}$ for 3 minutes at 30 seconds interval. Activity of glutathione $-\mathrm{S}-$ transferase was expressed as nmoles of CDNB conjugate formed/minute/mg of protein.

\section{(e) Estimation of total reduced glutathione}

Total reduced glutathione was determined by the method of (Sedlak and Lindsay 1968) modified according to the method of (Moron et al., 1979). $0.1 \mathrm{ml}$ of the test sample was precipitated with 5\% TCA. The precipitate was removed by centrifugation. To $2.0 \mathrm{ml}$ of the supernatant, added $2.0 \mathrm{ml}$ of $0.6 \mathrm{mg}$ of DTNB in $0.2 \mathrm{M}$ phosphate buffer ( $\mathrm{pH}$ 6.5). The absorbance was read at $412 \mathrm{~nm}$ against a blank containing TCA instead of sample. A series of standards treated in a similar manner were also run to determine the glutathione content. The amount of glutathione was expressed as $\mathrm{mg} / \mathrm{dl}$ for surm and $\mathrm{mg} / 100 \mathrm{~g}$ of tissues. 
(f) Assay of Lipid Peroxidation (LPO) - MDA

Malondialdehyde contents were estimated according the method of Buge and (Aust 1978).

To $1.0 \mathrm{ml}$ of the sample, $2.0 \mathrm{ml}$ of TCA - TBA - HCI reagent was added and mixed thoroughly. The solution was heated for 15 minutes in a boiling water bath. After cooling, the flocculent precipitate was removed by centrifugation at $1000 \mathrm{~g}$ for 10 minutes. The absorbance was determined at $535 \mathrm{~nm}$ against a blank that contains all the reagents except the sample. The results were expressed as nmoles of MDA formed/minute/mg protein using an extinction coefficient of the chromophore 1.56 $\mathrm{x} 105 \mathrm{Mcm}$ and expressed as moles of MDA formed/minute/mg protein.

\section{(g) Glutathione Determination}

This was based on the method of (Jollow et al. 1974). Reduced glutathione (GSH) forms the buck of non-protein sulfhydryl groups. This method is based on the formation of relatively stable yellow colour when Ellman's reagent is added to a sulfhydryl compound.2-nitro-5thiobenzoic acid, the chromophoric product resulting from the reaction of Ellman's reagent with reduced glutathione absorbs at $412 \mathrm{~nm}$. The absorbance at $412 \mathrm{~nm}$ is therefore proportional to glutathione content.

\section{(h) Doum}

Pipette $0.1 \mathrm{ml}$ of the sample. Add $0.9 \mathrm{~g}$ of distilled $\mathrm{H} 20$. Add $5 \mathrm{ml}$ of concentrated hydrogen chloride. Then shake the mixture. Add $2 \mathrm{ml}$ of 2, 4, DNPH-NEDA reagent. Stands for 10 minutes with occasional shaking. Dilute to $10 \mathrm{ml}$ with distilled water.Measure the absorbance at $520 \mathrm{~nm}$.

\section{Statistical Analysis}

The data were analyzed using General linear method of statistical analysis system( SAS 2004) Duncan Multiple range Test was used to compare the differences among means (Duncan, 1955). Data presented as percentages were transformed to the corresponding arcsine values (Warren and Gregory, 2005) before being statistically analyzed

$Y i j k=\mu+D i+B j+D B i j+E i j k$

Where: Yijk = any observation of the rabbit in the treatment; $\mu=$ Overall mean, common element to all observations; $\mathrm{Di}=$ Effect of the treatments(doum levels) $(\mathrm{i}=1,2,3$ and 4$) ; \mathrm{Bj}=$ Effect of the breeds( $j=1$ and $2 \mathrm{NZW}$ and CAL); $\alpha b i j=$ The interaction between two factor; Eijk= Random error component assumed to be normally distribute.

\section{Results and Discussion}

\section{Temperature-humidity index (THI):}

The estimated THI values (Table 1) indicated that during the experimental period (from April to, June 2017) rabbit bucks were exposed to severe heat stress (Maximum $\mathrm{THI}=29.68$ ) according to Marai et al. (2002).

\section{Reproductive Performance}

Data presented in Table 4 showed that, NEZ and CAL rabbits does fed diets supplemented with $0.9,0.6$ and $0.3 \mathrm{~g}$ doum $/ \mathrm{kg}$ diet using bucks treated with the same treatment, recorded conception and kindling rates; litter size and weight and bunny weight at birth and at weaning were significantly $(\mathrm{p} \leq 0.05)$ better, and in descending order, than of those recorded by does fed un-supplemented diet. Also, it can be noticed that doum treatments showed decrease in abortion and mortality rate when compared with control group. Growth rate of kit (g/kit/wk) was significantly increased as compared to control group. Mortality was decreased significantly ( $\mathrm{p}<$ 0.05) in treated groups compared to control. California does showed recorded significant higher conception rate, kindling rate, litter size at birth and at weaning and lower mortality rate compared to the NEZ breed. These results are in agreement with (Hassanien et al., 2019; Fawaz et al., 2019a, b; Abdel-Wareth et al., 2019a, b; 
Bozkurt et al., 2014; Hippenstiel et al., 2011). Zeidan et.,al (2001) Similarly, Kindling rate, Litter size at birth and at weaning in CAL were significantly better than NZW rabbits.The study showed that the different levels of doum fed to rabbit does had nosignificant effect $(\mathrm{P}>0.05)$ on body weight at mating, kindling and weaning. Rommers et al. (2001) and Szendro et al.(2002) stated that improvement in litter traits proved that, doum treatments are capable to improve the milking ability of the rabbit does which is reflected in her ability to suckle her young till weaning, and significant decrease in mortality compared with the control. The milk available per kit may also have a pronounced effect on the mortality of young rabbits. Besides that, the increase milk production may be due to increase in litter size at birth, where there was a positive correlation between the litter size at birth and milk yield (Lebas et al., 1997; and Rommers et al., 2001).(Mervet Ghazal et.,al 2016) showed that, Hy-Plus rabbit does fed diets supplemented with 750, 500 and $250 \mathrm{~g}$ doum using bucks treated with the same treatment, recorded conception and kindling rates; litter size and weight and bunny weight at birth and at weaning significantly $(\mathrm{p} \leq 0.05$ or 0.01$)$ better, and in descending order, than of those recorded by does fed un-supplemented diet.

\section{Milk yield and Milk composition}

The effect of doum supplementation on Milk yield and Milk composition of rabbit does is presented in Table( 5-6).milk yield and composition (protein; fat; lactose and ash) were significantly $(\mathrm{p} \leq 0.05)$ better than control group. Does fed diet of $0.90 \mathrm{~g}$ doum $/ \mathrm{kg}$ diet had significantly $(\mathrm{p}<0.05)$ higher milk yield and California breed showed significantly higher milk yield and improved milk composition as compared to Newzland breed. Similar results of milk yield and milk composition were observed by Mervat et.,al. (2016).

\section{Haematology, FSH and LH Characteristics}

The effect of doum supplementation on haematology, FSH, and $\mathrm{LH}$ of rabbitdoes is presented in Table 7. below. Does fed on diet supplemented with 0.90 gdoumpresented significantly $(\mathrm{p}<0.05)$ greater haemoglobin $(\mathrm{HB})$ concentration, RBC, N, E, and FSH than those fed on $0.30 \mathrm{~g}$ and $0.60 \mathrm{gdoum}$. (Write full rather than abbreviations). You described the results of other authors . Give references in line with your study and in contrast.

\section{Oxidative Enzymes Characteristics}

Results showed that does fed diet with 0.9 gdoum had significant decrease $(p<0.05)$ in MDA compared to other treatment groups, while significant increase $(p<0.05)$ in SOD concentration than thosefed 0.3 and $0.60 \mathrm{~g}$. Does fed diet supplemented with 0.30 and $0.60 \mathrm{~g}$ depicted greater influenceon glutathione transferasethan those of 0.90 and control group.However, doum supplementation of diet showed no significant $(\mathrm{p}>0.05)$ results on catalase, gluthathione and glutathione (Table 8).This results agreement with(Al-Masri, 2012) who reported thatdoum powder supplements showed a significant increase in the values of liver SOD,GPX, GST and catalase and a significant decrease in MDA at $\mathrm{p}<0.01 \& 0.001$ when compared with control group 
Table 4. Reproductive performance of rabbit does as affected by feeding diets supplemented with doum (Hyphaenethebaica).

\begin{tabular}{|c|c|c|c|c|c|c|c|c|c|c|}
\hline \multirow{2}{*}{ Reproductive parameter } & \multicolumn{4}{|c|}{ Doum levels (g/kg) } & \multicolumn{2}{|c|}{ Species } & \multirow{2}{*}{ SEM } & \multicolumn{3}{|c|}{$P$ - value } \\
\hline & T0_(0g) & $\mathrm{T} 1 \_(0.3 \mathrm{~g})$ & $\mathrm{T} 2 \_(0.6 \mathrm{~g})$ & T3_(0.9g) & NZW & CAL & & $\mathrm{D}$ & S & $\mathrm{D} \times \mathrm{S}$ \\
\hline No. of pregnant does & $18^{\mathrm{d}}$ & $22^{\mathrm{c}}$ & $24^{\mathrm{b}}$ & $26^{\mathrm{a}}$ & $24^{\mathrm{b}}$ & $26 .^{\mathrm{a}}$ & 0.48 & 0.0001 & 0.0001 & 0.0001 \\
\hline Conception rate $(\%)$ & $56.25^{\mathrm{d}}$ & $68.75^{\mathrm{c}}$ & $75.00^{b}$ & $81.25^{\mathrm{a}}$ & $75.00^{b}$ & $81.25^{\mathrm{a}}$ & 1.5 & 0.0001 & 0.0001 & 0.0001 \\
\hline Abortion rate $(\%)$ & $6.25^{\mathrm{a}}$ & $3.12^{\mathrm{b}}$ & $0.00^{\mathrm{d}}$ & $0.00^{\mathrm{d}}$ & $9.37^{\mathrm{a}}$ & $6.25^{\mathrm{b}}$ & 0.52 & 0.0001 & 0.0001 & 0.0001 \\
\hline Kindling rate $(\%)$ & $50^{\mathrm{d}}$ & $65.63^{\mathrm{c}}$ & $75^{\mathrm{b}}$ & $81.25^{\mathrm{a}}$ & $65.63^{\mathrm{b}}$ & $75^{\mathrm{a}}$ & 1.9 & 0.00 & 0.0001 & 0.0001 \\
\hline Litter size at birth (No) & $5.8^{\mathrm{c}}$ & $6.8^{\mathrm{b}}$ & $8^{\mathrm{a}}$ & $8.9^{\mathrm{a}}$ & $8^{\mathrm{b}}$ & $8.9^{\mathrm{a}}$ & 0.13 & 0.00 & 0.05 & 0.8186 \\
\hline Litter body weight at birth (g) & 261 & $312^{\mathrm{c}}$ & $390^{\mathrm{b}}$ & $445^{\mathrm{a}}$ & $368^{\mathrm{b}}$ & $445.9^{\mathrm{a}}$ & 0.215 & 0.0001 & 0.0001 & 0.3892 \\
\hline Doe body weight at kindling $(\mathrm{g})$ & 3430 & 3455 & 3449 & 3460 & 3465 & 3460 & 0.08 & $0.86^{\mathrm{NS}}$ & 0.62 & 0.815 \\
\hline Bunny weight at birth(g/kit) & $45.0^{\mathrm{bc}}$ & $46.0^{\mathrm{b}}$ & $48.8^{\mathrm{ab}}$ & $50^{\mathrm{a}}$ & $46^{\mathrm{b}}$ & $50.1^{\mathrm{a}}$ & 0.73 & 0.05 & 0.05 & 0.0080 \\
\hline Litter size at weaning (No) & $5^{\mathrm{c}}$ & $6^{\mathrm{b}}$ & $7.7^{\mathrm{a}}$ & $8.6^{\mathrm{a}}$ & $5^{b}$ & $8^{\mathrm{a}}$ & 0.19 & 0.0001 & 0.0001 & 0.4596 \\
\hline Pre weaningMortality rate (\%) & $13.8^{\mathrm{a}}$ & $11.8^{\mathrm{b}}$ & $3.75^{\mathrm{c}}$ & $3.4^{\mathrm{c}}$ & $37.5^{\mathrm{a}}$ & $10.11^{\mathrm{b}}$ & 0.34 & 0.0001 & 0.0001 & 0.0001 \\
\hline Doe body weight atweaning $(\mathrm{g})$ & 3200 & 3210 & 3155 & 3158 & 3210 & 3200 & 14.12 & $0.91^{\mathrm{NS}}$ & 0.84 & 0.092 \\
\hline
\end{tabular}

Means bearing different letter superscripts $(a, b, c, d)$ within the same row are significantly $(p \leq 0.05)$ different No. of inseminated does $=32$

Conception rate $(\%)=$ No. of pregnant does $\div$ No. of inseminated does $\mathrm{X} 100$.

Mortality rate was calculated individually according to the following equation:

Litter size at birth-Litter size at weaning / Litter size at birth X 100

The weaning $=30$ day 
Table 5: Milk yield (g) of rabbit does fed diets with different levels of doum (Hyphaenethebaica)

\begin{tabular}{|c|c|c|c|c|c|c|c|c|c|c|c|}
\hline \multicolumn{3}{|c|}{ Period (Days) } & \multicolumn{3}{|c|}{ Doum levels (g/kg) } & \multicolumn{2}{|l|}{ Species } & \multirow[b]{2}{*}{ SEM } & \multicolumn{3}{|l|}{ P-value } \\
\hline From & To & $\begin{array}{l}\text { T0 } \\
(0 \mathrm{~g})\end{array}$ & $\begin{array}{l}\mathrm{T} 1 \\
(0.3 \mathrm{~g})\end{array}$ & $\begin{array}{l}\mathrm{T} 2 \\
(0.6 \mathrm{~g})\end{array}$ & $\begin{array}{l}\mathrm{T} 3 \\
(0.9 \mathrm{~g})\end{array}$ & NZW & CAL & & $\mathrm{D}$ & $\mathrm{S}$ & $\mathrm{D} \times \mathrm{S}$ \\
\hline Birth & 7 & $416.5^{\mathrm{d}}$ & $497.00^{c}$ & $523.6^{\mathrm{b}}$ & $532.42^{\mathrm{a}}$ & $485.38^{\mathrm{b}}$ & $495.95^{\mathrm{a}}$ & 0.84 & 0.0001 & 0.0004 & 0.7654 \\
\hline 8 & 14 & $623.58^{c}$ & $700.5^{\mathrm{b}}$ & $738^{\mathrm{a}}$ & $742.8^{\mathrm{a}}$ & $697.56^{\mathrm{a}}$ & $705.00^{\mathrm{a}}$ & 1.16 & 0.0001 & 0.3208 & 0.9566 \\
\hline 15 & 21 & $882.36^{\mathrm{d}}$ & $970.86^{\mathrm{c}}$ & $1048.8^{b}$ & $1059.7^{\mathrm{a}}$ & $985.5^{\mathrm{b}}$ & $995.40^{\mathrm{a}}$ & 1.52 & 0.0001 & 0.0051 & 0.7375 \\
\hline 22 & 30 & $926.96^{c}$ & $1016.4^{\mathrm{b}}$ & $1207.2^{\mathrm{a}}$ & $1220.0^{\mathrm{a}}$ & $1089.4^{\mathrm{b}}$ & $1093.6^{\mathrm{a}}$ & 2.02 & 0.0001 & 0.5907 & 0.5643 \\
\hline \multicolumn{2}{|c|}{$\begin{array}{l}\text { Total milk yield } \\
(\mathrm{g})\end{array}$} & $2849.4^{\mathrm{d}}$ & $3184.7^{\mathrm{c}}$ & $3157.6^{b}$ & $3554.9^{\mathrm{a}}$ & $3257.8^{b}$ & $3289.9^{\mathrm{a}}$ & 5.2 & 0.0001 & 0.0001 & 0.7273 \\
\hline
\end{tabular}

Table 6 :Milk composition of NZW and CAL rabbit does fed diets with different levels of Doum (Hyphaenethebaica).

\begin{tabular}{|c|c|c|c|c|c|c|c|c|c|c|}
\hline \multirow[b]{2}{*}{ Milk composition } & \multicolumn{4}{|c|}{ Doum levels (g/kg) } & \multicolumn{3}{|l|}{ Species } & \multicolumn{3}{|c|}{ P-value } \\
\hline & $\begin{array}{l}\text { control } \\
(0 g)\end{array}$ & $\begin{array}{l}\mathrm{T} 1 \\
(0.3 \mathrm{~g})\end{array}$ & $\begin{array}{l}\mathrm{T} 2 \\
(0.6 \mathrm{~g})\end{array}$ & $\begin{array}{l}\mathrm{T} 3 \\
(0.9 \mathrm{~g})\end{array}$ & NZW & CAL & SEM & $\mathrm{D}$ & $S$ & $\mathrm{D} \times \mathrm{S}$ \\
\hline Milk Protein (\%) & $11.04^{\mathrm{d}}$ & $11.33^{\mathrm{c}}$ & $12.28^{\mathrm{b}}$ & $12.53^{\mathrm{a}}$ & $11.76^{\mathrm{b}}$ & $11.83^{\mathrm{a}}$ & 0.11 & 0.0001 & 0.022 & 0.2934 \\
\hline Milk ash (\%) & $3.65^{\mathrm{d}}$ & $3.82^{\mathrm{c}}$ & $4.04^{\mathrm{b}}$ & $4.13^{\mathrm{a}}$ & $3.91^{\mathrm{a}}$ & $3.91^{\mathrm{a}}$ & 0.15 & 0.0001 & 0.874 & 0.8973 \\
\hline $\operatorname{Milkfat}(\%)$ & $16.11^{\mathrm{d}}$ & $17.87^{\mathrm{c}}$ & $17.84^{\mathrm{b}}$ & $18.33^{\mathrm{a}}$ & $17.47^{\mathrm{a}}$ & $17.49^{\mathrm{a}}$ & 0.05 & 0.0001 & 0.286 & 0.6256 \\
\hline Milk lactose (\%) & $3.77^{\mathrm{d}}$ & $3.96^{\mathrm{c}}$ & $4.35^{\mathrm{b}}$ & $4.57^{\mathrm{a}}$ & $4.18^{\mathrm{a}}$ & $4.16^{\mathrm{a}}$ & 0.03 & 0.0001 & 0.622 & 0.0119 \\
\hline
\end{tabular}

Table 7. Effect of doum supplementation in diet of rabbit does on haematology, fsh and lh characteristics.

\begin{tabular}{|c|c|c|c|c|c|c|c|c|c|c|}
\hline \multirow[b]{2}{*}{$\begin{array}{l}\text { Reproductive } \\
\text { Parameter }\end{array}$} & \multicolumn{4}{|c|}{ Doumlevels (g/kg) } & \multicolumn{3}{|l|}{ Species } & \multicolumn{3}{|l|}{ P-value } \\
\hline & $\begin{array}{l}\text { T0 } \\
(0 \mathrm{~g})\end{array}$ & $\begin{array}{l}\mathrm{T} 1 \\
(0.3 \mathrm{~g})\end{array}$ & $\begin{array}{l}\mathrm{T} 2 \\
(0.6 \mathrm{~g})\end{array}$ & $\begin{array}{l}\text { T3 } \\
(0.9 \mathrm{~g})\end{array}$ & NZW & CAL & SEM & $\mathrm{D}$ & $\mathrm{S}$ & $\mathrm{D} \times \mathrm{S}$ \\
\hline $\mathrm{HBg} / \mathrm{dl}$ & $11.85^{\mathrm{b}}$ & $12.10^{\mathrm{ab}}$ & $12.70^{\mathrm{ab}}$ & $13.5^{\mathrm{a}}$ & 12.78 & 12.80 & 0.35 & 0.05 & 0.18 & 0.05 \\
\hline $\operatorname{PCV}(\%)$ & $35.67^{\mathrm{b}}$ & $35.50^{\mathrm{b}}$ & $34.67^{\mathrm{b}}$ & $44.62^{\mathrm{a}}$ & $35.50^{\mathrm{b}}$ & $38.74^{\mathrm{a}}$ & 1.20 & 0.04 & 0.2876 & 0.74 \\
\hline $\mathrm{RBC}\left(\mathrm{x} 10^{6}\right)$ & $4.77^{b}$ & $5.59^{\mathrm{ab}}$ & $8.86^{\mathrm{a}}$ & $8.86^{\mathrm{a}}$ & $8.86^{a}$ & $8.86^{\mathrm{a}}$ & 0.16 & 0.05 & 0.85 & 0.8774 \\
\hline $\mathrm{N}(\mu \mathrm{L})$ & $14200^{\mathrm{b}}$ & $13600^{\mathrm{b}}$ & $13400^{b}$ & $22300^{a}$ & $13400^{\mathrm{b}}$ & $13600^{\mathrm{b}}$ & 1.84 & 0.00 & 0.021 & 0.31 \\
\hline $\mathrm{E}(\%)$ & $19.5^{\mathrm{b}}$ & $21.00^{\mathrm{ab}}$ & $26.50^{\mathrm{a}}$ & $24.31^{\mathrm{a}}$ & $26.50^{\mathrm{a}}$ & $24.31^{\mathrm{a}}$ & 1.70 & 0.04 & 0.022 & 0.29 \\
\hline $\mathrm{FSH}(\mathrm{LU} / \mathrm{ml})$ & $2.90^{\mathrm{c}}$ & $2.85^{\mathrm{c}}$ & $8.45^{b}$ & $15.43^{\mathrm{a}}$ & $8.45^{\mathrm{b}}$ & $13.43^{\mathrm{a}}$ & 1.15 & 0.00 & 0.05 & 0.31 \\
\hline LH (LU/ml) & 0.02 & 0.08 & 0.09 & 0.12 & 0.09 & 0.08 & 0.02 & $0.29^{\mathrm{NS}}$ & 0.0419 & 0.22 \\
\hline
\end{tabular}

a,b,c: Means in a row with different superscripts are statistically significant $(\mathrm{P}<0.05)$

NS = Not significant 
Table 8. Effect of doum supplementation on oxidative enzymes characteristics of rabbit does

\begin{tabular}{|c|c|c|c|c|c|c|c|c|c|c|}
\hline \multirow{2}{*}{$\begin{array}{l}\text { Parameters(Oxidatie } \\
\text { Enzymes) }\end{array}$} & \multicolumn{4}{|c|}{ Doumlevels (g/kg) } & \multicolumn{2}{|c|}{ Species } & \multirow[b]{2}{*}{ SEM } & \multicolumn{3}{|c|}{ P-value } \\
\hline & $\begin{array}{c}\text { T0 } \\
(0 \mathrm{~g}) \\
\end{array}$ & $\begin{array}{c}\mathrm{T} 1 \\
(0.3 \mathrm{~g}) \\
\end{array}$ & $\begin{array}{c}\mathrm{T} 2 \\
(0.6 \mathrm{~g}) \\
\end{array}$ & $\begin{array}{c}\text { T3(0.9 } \\
\mathrm{g})\end{array}$ & NZW & CAL & & $\mathrm{D}$ & S & $\mathrm{D} \times \mathrm{S}$ \\
\hline $\operatorname{Doum}(\mathrm{g} / \mathrm{dl})$ & 0.00 & 0.58 & 0.60 & 0.63 & 0.57 & 0.58 & 0.14 & $0.5^{\mathrm{NS}}$ & 0.5 & 0.6 \\
\hline $\operatorname{MDA}(\mathrm{g} / \mathrm{dl})$ & $3.18^{\mathrm{a}}$ & $2.84^{\mathrm{ab}}$ & $2.09^{\mathrm{bc}}$ & $1.97^{\mathrm{c}}$ & 3.09 & 3.18 & 0.17 & 0.014 & 0.017 & 0.019 \\
\hline Catalase (U/l) & 1.34 & 1.28 & 1.34 & 1.24 & 1.28 & 1.34 & 0.02 & $0.19^{\mathrm{NS}}$ & 0.17 & 0.18 \\
\hline SOD (NL) & $66.45^{\mathrm{a}}$ & $56.21^{\mathrm{b}}$ & $54.66^{\mathrm{b}}$ & $64.34^{\mathrm{a}}$ & $66.45^{\mathrm{a}}$ & $64.34^{\mathrm{a}}$ & 1.42 & 0.01 & 0.03 & 0.04 \\
\hline $\begin{array}{l}\text { Glutathione } \\
\text { transferase(HI) }\end{array}$ & $1.16^{\mathrm{ab}}$ & $1.22^{\mathrm{a}}$ & $1.21^{\mathrm{a}}$ & $1.11^{\mathrm{b}}$ & $1.21^{\mathrm{a}}$ & $1.22^{\mathrm{a}}$ & 0.01 & 0.05 & 0.87 & 0.89 \\
\hline $\begin{array}{l}\text { Glutathione Peroxide } \\
(\mu \mathrm{L})\end{array}$ & $232.06^{\mathrm{a}}$ & $230.00^{\mathrm{b}}$ & $257.14^{\mathrm{ab}}$ & $228.06^{\mathrm{b}}$ & $230.0^{\mathrm{b}}$ & $228.06^{\mathrm{b}}$ & 9.7 & 0.05 & 0.89 & 0.877 \\
\hline Glutathione $(\mathrm{Hg} / \mathrm{ml})$ & $0.18^{a}$ & $0.13^{\mathrm{c}}$ & $0.14^{\mathrm{b}}$ & $0.14^{\mathrm{bc}}$ & $0.14^{\mathrm{b}}$ & $0.14^{\mathrm{b}}$ & 0.01 & $2.91^{\mathrm{NS}}$ & 0.59 & 0.56 \\
\hline $\begin{array}{l}\text { Reduced glutathione } \\
(\mu \mathrm{mol} / \mathrm{L})\end{array}$ & 0.07 & 0.07 & 0.06 & 0.06 & 0.06 & 0.06 & 0.00 & $0.43^{\mathrm{NS}}$ & 0.073 & 0.53 \\
\hline
\end{tabular}

a,b,c: Row means with different superscripts are statistically significant $(* \mathrm{P}<0.05)$

NS $=$ Not significant

\section{References}

Abdel-Rahim, E.A., El-Beltagi, H.S., Fayed, A.S., (2011). 'Comparative studies on the influences of Juniperusphoenicea and Hyphaenethebaica as hypoglycemic factors in diabetic rats ', Advances in Food Sciences 33, pp.128-132.

Abdel-Wareth, A.A.A., Ahmed, A.E., Hassan, H.A., Abd El-Sadekd, M.S., Ghazalah, A.A., Lohakare, J. (2019). 'Nutritional impact of nano-selenium, garlic oil, and their combination on growth and reproductive performance of male Californian rabbits'. Animal Feed Science and Technology 249, pp. 37-45.

Abdel-Wareth, A.A.A., .Taha, E.M.M., Südekum, K-H., Lohakare, J. (2018). 'Thyme oil inclusion levels in a rabbit ration: Evaluation of productive performance, carcass criteria and meat quality under hot environmental conditions '. Animal Nutrition, 4, pp. 410-416. https://doi.org/10.1016/j.aninu.2018.02.004

Abdel-Wareth, A.A.A., Hammad, S.K., Ahmed, H., (2014). 'Effects of Khaya senegalensis leave on performance, carcass traits, hematological and biochemical parameters in rabbits ' Experimental and Clinical Sciences, 13, pp. 502-512.

Abdel-Wareth, A.A.A., Kehraus, S., Hippenstiel, F., Südekum K.-H., (2012). 'Effects of thyme and oregano on growth performance of broilers from 4 to 42 days of age and on microbial counts in crop, small intestine and caecum of 42-day-old broilers ' Animal Feed Science and Technology 178, pp. 198-202.

Abdel-Wareth, A.A.A., Lohakare, J. (2020). 'Productive performance, egg quality, 
nutrients digestibility, and physiological response of bovans brown hens fed various dietary inclusion levels of peppermint oil'. Animal Feed Science and Technology 267, pp.114554.

https://doi.org/10.1016/j.anifeedsci.2020.11 4554

Abdel-Wareth, A.A.A., Kehraus, S., Südekum, K-H., (2019). 'Peppermint and its respective active component in diets of broiler chickens: Growth performance, viability, economics, meat physicochemical properties, and carcass characteristics'. Poultry Science, 98, pp. 3850-3859, https://doi.org/10.3382/ps/pez099

Abdel-Wareth, A.A.A., Hammad, S., Khalaphallah, R., Salem, W.M., Lohakare, J. (2019). 'Synbiotic as eco-friendly feed additive in diets of chickens under hot climatic conditions'. Poultry Science, 98, pp. 4575-4583, https://doi.org/10.3382/ps/pez115

Abdel-Wareth, AA.A. (2016). 'Effect of dietary supplementation of thymol, synbiotic and their combination on performance, egg quality and serum metabolic profile of HyLine Brown hens '. British Poultry Science, 57, pp. 114-122.

Ali, W.A.H., Ghazal, M.N., (2013) 'In vivo and in vitro studies on effect of Ganoderma on rabbit reproductivity, semen preservation and artificial insemination.' J. Anim. Poult. prod., Mansoura Univ., 4(12), pp. 715-731.

Al-Masri, S., (2012). 'Effect of Doum And Methionine Combination on Hepatotoxicity in Rats. Australian Journal of Basic and Applied Sciences 6(6), pp. 392-397.

Amer, S.A., Naser, M.A.F., Abdel-Wareth, A.A.A. et al. (2020). 'Effect of dietary supplementation of alpha-galactosidase on the growth performance, ileal digestibility, intestinal morphology, and biochemical parameters in broiler chickens'. BMC Vet

Res 16, pp. 144.

https://doi.org/10.1186/s12917-020-02359

Aremu, A., Fadele, O. (2011). 'Study of some properties of doum palm fruit (Hyphaenethebaica Mart.) in relation to moisture content '. Afr. J. Agric. Res., 6, pp. 3597-3602.

Bozkurt, M., Friederike Hippenstiel, AbdelWareth, A.A.A., Kehraus, S., Küçükyilmaz, K., Südekum, K.-H., (2014). 'Effects of selected herbs and essential oils on performance, egg quality and some metabolic activities in laying hens-a review ' European Poultry Science, 78. 2014, ISSN 1612-9199

Burkill, H.M, editor (1997). 'The useful plants of west tropical africa.2nd ed. Vol. 4. Kew: Royal Botanical Garden. pp. 371-373

Duncan, D.B. (1955). 'Multiple ranges and multiple F-test', Biometrics, 11, pp.142.

Fawaz, M., Abdel-Wareth, AA.A.., Hassan, H., Südekum, K-H. (2019). 'Applications of nanoparticles of zinc oxide on productive performance of laying hens', SVUInternational Journal of Agricultural Sciences, 1(1), pp. 34-45. doi: 10.21608/svuijas.2019.67083

Fawaz, M., Südekum, K-H., Hassan, H., AbdelWareth, A.A.A. (2019). 'Effects of nanoparticles of zinc oxide on productive performance of laying hens. - a review.', SVU-International Journal of Agricultural Sciences, 1(1), pp. 13-20. doi: 10.21608/svuijas.2019.67076

Habig, W.H., Pabst, M.J., Jakoby, W.B. (1974). 'Glutathione S-transferases. The first enzymatic step in mercapturic acid formation '. Journal of Biological Chemistry 249, pp.7130-7139. 
Hassanien, H., Baiomy, A., Hassan, H., Badry, H. (2019). 'The effect of dietary doum supplementation on- productive and reproductive performance of male rabbits in Upper Egypt', SVU-International Journal of Agricultural Sciences, 1(1), pp. 70-82. doi: 10.21608/svuijas.2019.67087.

Hetta, M.H., Yassin, N.Z. (2006). 'Comparative studies on hypocholesterolemic effect of different fractions of Hyphaenethebaica (Doum) in experimental animals', Pharmazie, 61(3), pp. 230-232

Hetta, M.H., Yassin, N.Z., El Shaer, M.A. (2005). 'Effect of Hyphaenethebaica on the spermatogenesis of male rats'. Egypt. Med. J. N.R.C.; 4(3):, pp.35-39.

Hippenstiel, F., Abdel-Wareth, A.A.A.,

Kehraus, S., Südekum, K.-H. (2011).

'Effects of selected herbs and essential oils, and their active components on feed intake and performance of broilers - a review ', Arch.Geflügelk., 75 (4), pp. 226-234.

Lebas, F., coudert, P., Rouvier, R., de Rochambeau, H. (1997). 'The Rabbit Husbandry, Health and Production. Rome: Food and Agriculture Organization of the United Nation.

Marai, I.F.M., Ayyat, M.S., Abdel-Monem, U.M. (2001). 'Growth performance and reproductive traits at first parity of New Zealand White female rabbits as affected by heat stress and its alleviation under Egyptian conditions. Journal of Trop. Animal Health Production, 33, pp. 1-12.

Mervat, N. Ghazal. Safaa, A. Barakat ;Ali, W.A.H, Rowida, M. Riad (2016) 'Effect of supplementing doum (hyphaenethebaica) to diets on reproductive and productive traits in rabbits Egypt. Poult. Sci. Vol (36) (III), pp. $711-723$.

Misra, H.P., Fridovich, I. (1972). 'The role of superoxide anion in the autoxidation of epinephrine and a simple assay for superoxide dismutase'. Journal of Biological Chemistry 247, pp. 3170-3175.

Rommers, J. M., Meijerhof, R., Noordhuizen, J. P.T. M., Kemp, B., (2001). 'Effect of different feeding levels during rearing and age at first insemination on body development, body composition and puberty characteristics of rabbit does'. World Rabbit Sci., 9, pp.101-108.

SAS (2004). 'SAS User's Guide: Statistics, version 5 Edition SAS Inst., Inc., Cary, NC, US.

Shehu B.B., Gidado A, Buratai L.B. (2014) 'Hypoglycaemic effect of extract of Hyphaenethebaica (L) Mart fruit pulp in normal and alloxan induce diabetic rats. Journal of Applied Bioscience 6, pp. 6-15.

Szendro, zs., Randai, I., Birone-Nemeth, E., Romvari, R., Milists, G., (2002). 'Effect of live weight on the carcass traits of pennon white rabbits. 3rd Int. Symp'. "Animal Science Days", Sept. 26-29, 1995, Bled, Slovenia.

Warren, J.E., Gregory, G., (2005). 'Statistical Methods in Bioinformatics: An Introduction (Statistics for Biology and Health) ', Springer Science press, New York, US

Warren, J. E.; and Gregory, G.,(2005). Statistical Methods in Bioinformatics: An Introduction (Statistics for Biology and Health). Springer Science press, New York, USA. 